\title{
Applying sustainable employment principles in the tourism industry: righting human rights wrongs?
}

\begin{abstract}
This paper argues that issues of employment in tourism raise fundamental concerns in the context of basic human rights. Such rights lie at the heart of intentions within the UN's 2030 Agenda for Sustainable Development which advocates "full and productive employment and decent work for all". This paper contends that concerns relating to tourism employment, therefore, lie at the heart of the sustainability debate within international tourism. At a time of sustained growth in demand for tourism worldwide, the industry faces persistent challenges with respect to employment, highlighted, inter alia, with respect to low pay, precarious security, poor working conditions, high labour turnover, intersectional disadvantage, occupational ghettoization and employee sexual and physical abuse that can represent modern slavery. These issues appear to be systemic, structural and universal across all countries and within both formal and informal economies. In this paper we assess these issues from a human rights perspective at three levels, the individual employee, their family and their community. We then consider whether a sustainability-informed approach to tourism employment can mediate potential human rights violations, building on the ethical case proposed by notions of sustainable HRM. Conclusions are reached which place clear responsibility for change with governments through legislation and enforced regulation; private sector employers; and consumers.
\end{abstract}

Key words: tourism; employment; human rights; sustainability; sustainable employment 


\section{Applying sustainable employment principles in the tourism industry: righting human rights wrongs?}

\section{Introduction}

This paper is built on the foundations of two pillars. The first is recognition that tourism employment is a neglected area in discussion about sustainability in international tourism, although there is increasing interest in this angle (Baum, Cheung, Kong et al, 2016; Baum, 2018; Winchenbach, Hanna and Miller, 2019). The second and equally important pillar that we consider in this paper is that of addressing tourism employment from the perspective of human rights considerations, which is also on the agenda at the margins but not as the core of sustainability discussions in tourism (Puneet, 2015). Work that does address human rights in the context of tourism has focused more on the rights of citizens to access tourism as leisure (McCabe and Diekmann, 2015) rather than the rights of those working on the other side of the fence. Such neglect is somewhat surprising in that sustainability is at the heart of the ILO's notion of decent work within which rights are clearly emphasised. Decent work is described as existing under "conditions of freedom, equity, security and dignity, in which rights are protected and adequate remuneration and social coverage are provided" (ILO, 1999: 15). This, in turn, strongly informs the aspirations behind Article 8 of the UN's 2030 Agenda for Sustainable Development which advocates "full and productive employment and decent work for all" (United Nations 2015).

The purpose of this paper is to consider whether the ethical and practical challenges associated with much tourism employment worldwide, can be ameliorated by adopting a human rights perspective on the complex environment within which they exist and persist. There is an increasing academic and applied interest in rights-based approaches to tourism and its development in a diversity of industry contexts and addressing specific dimensions within the human rights debate (see, for example, the edited work of Nguyen and Ngo, 2019 that highlights the impact of tourism growth on the rights of children in Vietnam and Myanmar). Our interest here is with the specific context of tourism work and whether issues that are evident in the tourism workplace, in fact, raise wider concerns from a rights perspective. Are there systemic, structural, economic and cultural characteristics of tourism employment that reflect divergence from basic human rights, both of those who work in the industry and of their immediate dependents within family and community? We aim to build on a growing narrative which applies a human rights lens to employment in a more general sense (for example, Alston, 2005; Fenwick and Novitz, 2010; Kolben, 2010; Islam and Jain, 2013; Fey and MacNaughton, 2015) and which, at an organisational level, seeks to interrogate the 
relationship between employee-focused corporate social responsibility and ethical aspects of human resource management (Morgeson et al, 2013; Voegtlin and Greenwood, 2016).

In this paper, we seek to test key dimensions of tourism employment against accepted human rights criteria. We then assess the outcome of this analysis against the emergent framework in tourism that seeks to apply sustainability principles to human resource management or employment. Influenced by notions of decent work, sustainable human resource management (Zaugg, Blum and Thom, 2001; Ehnert, 2009; Ehnert and Harry, 2012; Ehnert, Parsa, Roper et al, 2016, Baum et al, 2016; Baum, 2018; Winchenbach et al, 2019) (or sustainable employment as we style it here) has emerged as a framework with which to achieve all-round decency across all dimensions of paid work. It is worthwhile examining what sustainable HRM actually means in this context. Ehnert et al $(2016,90)$ define it as " the adoption of HRM strategies and practices that enable the achievement of financial, social and ecological goals, with an impact inside and outside of the organisation and over a long-term time horizon while controlling for unintended side effects and negative feedback". The application of sustainable HRM, as a critical lens to the context of tourism, is relatively recent (Baum et al, 2016; Baum, 2018) but it appears to have significant utility in providing the platform for advocacy for change at a policy and practitioner level. It also implies the adoption of practices that readily accommodate a recognition of human rights considerations within tourism employment.

This paper is organised as follows. We start by considering the complex evidence with respect to employment in tourism and highlight the extent to which it meets objective criteria for 'decent work'. We develop this discussion by considering such work in the context of agreed international standards for human rights within the workplace. We then assess the utility of sustainable HRM or employment principles as a means by which to challenge the potential for human rights violations in tourism employment. Conclusions are drawn with respect to future research requirements in this area.

\section{Employment in tourism - the good, the bad and the very ugly}

Discourse relating to employment in the tourism industry is underpinned by a cacophony of contradictions or paradoxes, of which interpretations are contingent on stakeholder perspectives that are both ideologically and practically framed. Inter-alia, all or some of location, political climate, economic context, socio-cultural values, industry sector, business size and ownership, location within the formal or informal economy, composition of the workforce and the working roles of individual actors, all of which feed into an employment environment that is diverse as it is 
fragmented (Baum, 2018; 2019). Such paradoxes are rife within tourism in general and specifically emerge with reference to employment (Iverson, 2000; Furunes, 2005; Sandoff, 2005). They may relate to the recruitment difficulties faced by businesses in locations of high unemployment; companies that avow a commitment to gender and other forms of intersectional equity while maintaining ceilings or barriers that inhibit real opportunity; or a corporate or industry rhetoric of positivity about tourism employment ("our employees are our greatest assets") (Solnet. Karlj and Baum, 2014) which sits uncomfortably alongside widespread evidence of low pay (De Beer et al, 2014; Robinson, 2013; Pizam, 2015); disregard for employment law; hostility to workplace organisation (Bergene et al, 2015); persistent issues with respect to occupational health and safety (Sonmez et al, 2016); high labour turnover (Brown et al, 2015; Akgunduz and Eryilmaz, 2018); precarious employment opportunities (McDowell et al, 2009; Ross, 2009, Anderson, 2010; Robinson et al, 2019); and poor working conditions (Pienaar and Willemse, 2008; Baum, 2015). Despite recognition of such paradoxes, and their consequences for key tourism stakeholders (employees, employers, governments and communities), the response is widely characterised by tired rhetoric from competent international agencies (Baum and Weinz, 2010) and policy inertia from governments, the private sector and key bodies associated with the tourism industry (Solnet, Nickson et al, 2014; Baum, 2018).

Notwithstanding the challenges which such contradictions pose, globally tourism continues to grow as a sector and, with it, levels of employment are rising across both developed and emerging economies. While the nature of work in the sector is by no means static, fuelled by technological, structural, social and demographic change, it is clear that tourism will remain a significant employer of labour at all skills levels into the foreseeable future (Solnet, Baum et al, 2014; Solnet et al, 2016). There is little evidence that, across the global piece, working conditions, job quality and remuneration in tourism are improving in line with the growth of the industry and, indeed, when the very substantial informal sector is taken into consideration, it is arguable that, in some respects they are deteriorating. There is also an evident failure to address workplace, job quality and skills issues alongside the planning and development of tourism facilities, infrastructure and markets at a destination or national level (Baum, 2018; Baum, 2019). Tourism is certainly far from delivering the ILO's notion of decent work (ILO, 2012) and taking aboard guidance provided by Article 8 of the UN's 2030 Agenda for Sustainable Development which advocates "full and productive employment and decent work for all" (United Nations, 2015). 
Tourism employment is diverse in both vertical and horizontal terms and is located across very different sub-sectors (such as travel facilitation, transport, accommodation, food services, attractions, heritage, events) at multiple levels within micro, medium and large organisations, both local and multinational. It is geographically dispersed and can be found in remote areas where a local skilled workforce is not readily available. It is also work that can be greatly influenced by the impacts of seasonality and wider insecurities, can be anti-social in the demands it makes on the working day and is frequently perceived to be of low status and limited desirability from a career perspective (Mooney, 2018). Tourism is an industry that is characterised by a high level of worker mobility, frequently through the exploitative employment of migrant labour (Duncan et al, 2013; Janta et al, 2012). Finally, tourism is at the forefront of the emergent collaborative or gig economy, within which the long-term employment consequences remain uncertain (Dredge and Gyimóthy, 2015; Moraga, 2017). Therefore, it is difficult to generalise about job characteristics, working conditions and job quality within tourism. Writing some 20 years ago, (Wood, 1997:198) provided a challenging perspective on work in one of tourism's largest sub-sectors, hospitality, when he declared that "hospitality work is largely exploitative, degrading, poorly paid, unpleasant, insecure and taken as a last resort or because it can be tolerated in the light of wider social and economic commitments and constraints."

There has been little evidence of significant change to this bleak assessment over time (Baum, 2015; 2019). Many areas of tourism in both developed and less developed countries include work which remains poorly paid, and lacking in social respect and value (see, for example, De Beer, Rogerson, and Rogerson, 2014); hostile to workplace organisation (Bergene, Boluk, and Buckley, 2015); or is located in an environment where employer practice flies in the face of both legal and ethical standards and expectations (Poulston, 2008; The Guardian, 2016). It is also widely described as "low skills" (see Ladkin, 2011; Shaw and Williams, 1994; Westwood, 2002 among others) although this is challenged as western-centric by other authors (Burns, 1997; Nickson et al, 2003). In its broadest interpretation, tourism work can include engagement with exploitative employment contexts, bordering on modern slavery that includes child labour, child sex work, child trafficking but also the exploitation of vulnerable adults through forced labour (Robinson, 2013; Armstrong, 2017). Modern slavery, in this context, is rightly highlighted by Robinson (2013:94) as a "profound violation of human rights".

However, there is also recognition of an inherent ambiguity with respect to interpretations of job quality in the sector (Knox et al, 2015; Knox, 2016) in the sense that what may be perceived as a 
"bad" job from an external perspective may also be seen entirely differently by those involved in the work. Perceived quality of work in tourism is contingent on the macro-context (economic and sociocultural) in terms of, for example, gender and ethnicity (see Adler and Adler, 2004; McDowell et al, 2007) as well as that of the attitude and aspirations of the individual in assessing the relative job opportunities available within the sector and the wider economy (Gursoy et al, 2013). It is also clear that there are many examples of tourism companies that commit to broad-based corporate social responsibility and exhibit the highest standards in terms of ethical employment, offering work and careers on par with some of the best employers worldwide (Hughes and Scheyvens, 2016).

In a sector such as tourism, there are real issues with respect to the extended and opaque supply or value chains that support the 'front-line' businesses and how these translate in terms of responsibility for working conditions and employment (Becker et al, 2010). As O'Brien and Dhanarajan (2016:551) note, "companies' failures to remediate more general supply chain responsibility issues probably remain the biggest problem of all" and, in tourism, these links extend across a wide range of sectors, both local and international. Consideration of employment in the industry is further complicated because of the fast changing nature of the business structures that are evident in the form of partnerships, alliances, franchising and off-shored ownership models coupled with multi-employer sites, outsourcing, temporary forms of employment and selfemployment. Furthermore, tourism, perhaps more so than most others sectors of the economy, broadly operates within two parallel and largely interdependent worlds in organisational terms, often offering notionally similar work (as cooks/ chefs, servers etc.) across both (although consumer experiences traverse the boundary in a seamless manner). These worlds represent, on the one hand, businesses within the formal, recognised and often registered (with tourism authorities) industry alongside, on the other, a grey or informal and unregulated tourism economy which can include a significant proportion of the total sector in many countries (McDonald, 1994; Leonard, 2000; Jones et al, 2004; Flodman Becker, 2004; Moraga, 2017). This is frequently in the form of self-employment or family-based work. Furthermore, with the emergence of a growing collaborative or gig economy in tourism onto the international stage, the distinction between the formal and the informal is becoming increasingly blurred and, arguably, problematic from an employment perspective (Moraga, 2017). These conditions only heighten the precarious nature of much tourism employment.

In summary, then, there is ample evidence that tourism can (but by no means always will) include 
- Work that is poorly paid relative to other sectors in the economy, frequently at levels that are unsustainable in the informal economy and below the legal threshold in countries where a minimum wage level applies

- Work in challenging and physically demanding conditions (hot, noisy, unsanitary) where there is limited regard to health and safety considerations

- Work that is located remote from major centres of population, requiring employees to live away from home or to relocate to remote areas

- Work that is subject to the effects of stochastic demand due to seasonality and uneven demand during the day/ week/

- Work that demands delivery of services at times when the majority of the population are at leisure (evenings, weekends, holiday periods)

- Work that is segregational and discriminatory against opportunity on the basis of gender, ethnicity, age and disability

- Work that is demeaning and degrading in conditions of slavery and/ or sexual exploitation

Advocacy for improvements in working conditions within tourism is not new and has been led by the ILO's decent work agenda (Boardman et al, 2015; Baum, 2019). Such acknowledgement is also the focus of the UN in the eighth of its sustainable development goals (United Nations, 2015). The next question we address in this paper is whether these conditions of work across contemporary tourism constitute a challenge to the human rights of employees, members of their families and their communities.

\section{A human rights perspective on tourism employment}

Concern for employment and working conditions is recognised as a key human right within the Universal Declaration of Human Rights, proclaimed by the United Nations in 1948 (UN, 1948). Article 23 states that 
i. Everyone has the right to work, to free choice of employment, to just and favourable conditions of work and to protection against unemployment.

ii. Everyone, without any discrimination, has the right to equal pay for equal work.

iii. Everyone who works has the right to just and favourable remuneration ensuring for himself and his family an existence worthy of human dignity, and supplemented, if necessary, by other means of social protection.

iv. Everyone has the right to form and to join trade unions for the protection of his (sic) interests.

In seeking to assess whether aspects of tourism employment present challenges to these and wider human rights of those working within the tourism industry and/ or members of their family or communities, we are further informed by the United Nation's (2011) Guiding Principles on Business and Human Rights (GP). These clearly delineate the responsibility of businesses to respect human rights in their broadest sense, including the commitment that the Universal Declaration of Human Rights (UDHR) places on the right to full employment and decent work and the International Labour Office's similar focus on decent work. The Guiding Principles on Business and Human Rights call for businesses to address due dilligence that covers adverse human rights impacts which the business enterprise may cause or contribute to through its own activities, or which may be directly linked to its operations, products or services by its business relationships through its value chain. Frey and McNaughton (2016:1) capture the intent of the UDHR, the ILO and the GP with respect to work and employment when they state that "it is decent work-that is, work that respects the human rights of the worker-that is a necessary component of a strategy to eliminate multi-dimensional poverty, as well as a key aspect of human dignity"

We can conceptualise human rights in the context of tourism employment at three levels. The core human rights area and, undoubtedly the most widely considered in the context of employment within tourism, is that of the individual whose life is bounded by their work and employment within tourism. It is the area that most clearly falls within the responsibility purview of the employer and, indeed the State. However, employment cannot be seen in isolation of the impact that working conditions have on the lives of the employee outside of the workplace and also on their immediate dependents, in many instances, their family. Here we are extending discussion beyond the notion of work-life balance and employee well-being for the worker although these are important considerations. We are concerned with how the nature of employment of one family member, in this case within tourism, impacts on the lives and, therefore, the rights of other family members. 
Finally, we are concerned about the relationship between employment in tourism and the wider community within which such work is located and of which the worker is part and how this relationship may impact on the wider rights of community members.

\section{(Figure 1 about here)}

Human rights in an employment context are about more than economic rights although these are central to the ILO's concept of decent work. They are also about work which provides opportunities to acquire knowledge and skills, form friendships, integrate into the community, and achieve selfrealization (Gross, 2010). International human rights law sets out the entitlements and freedoms of individuals in family contexts, although the family as a unit is not in and of itself entitled to human rights protection. All individuals have equal rights to a family life, which must be recognised by their employer, other family members, the community and the State. The UN's Universal Declaration of Human Rights, in Articles 24, 25 and 26 makes reference to the right to rest and leisure including paid periods away from work, to adequate health standards and to education in support of their development. These rights are of particular relevance in the context of family as highlighted here. Community rights include environmental rights, such as the right to clean air, pure water, and healthy soil; worker rights, such as the right to living wages and equal pay for equal work; rights of nature, such as the right of ecosystems to flourish and evolve; and democratic rights, such as the right of local community self-government, and the right to free and fair elections.

Meyer (2015) highlights the challenges of adopting global human rights standards in the workplace, noting the reluctance of the global south to see such employment standards adopted within World Trade Organisation rules. Such adoption could have the effect of reducing the flight of capital to labour markets where costs are low and workplace rights are neglected. Much tourism, however, is place-dependent so that the sector does not significantly benefit from movement of visitors away from, for example, Paris, Venice or London to other destinations with the aim to reduce labour costs. However, emergent sectors which are not tied to place in the same way, such as cruising, certainly do benefit from accessing low cost labour markets and utilising vessels that are registered in a lowregulation country.

Mantouvalou (2012) explains the on-going debate as to whether labour rights are, in fact, human rights. She notes that some argue, from a legalistic perspective that unless labour rights are wholly enshrined into human rights law, they cannot be construed as human rights. An alternative 
perspective is instrumental, letting rights in the workplace be tested in the courts to determine whether they have the universality of human rights. Finally, a third perspective is to adopt a normative perspective, arguing that it is necessary to clarify exactly what a human right is, and assesses, given the arrived at definition, whether certain labour rights can thus be construed as human rights. Our argument, illustrated below, is that, from a normative perspective, much work undertaken in tourism challenges the broad scoping of human rights as defined by the UN and the ILO, allied to Cheruiyot and Maru's (2014:154) focus on human rights as "bottom-up, moral and legalistic, with the individual at the centre, not the corporation". Human rights, therefore, are based on the "inherent dignity of every person". Tensions within this debate, then are faced with the paradox of neo-liberal beliefs in deregulated workspace where regulation is seen as detrimental to growth and foreign direct investment (FDI) juxtaposed against a social justice perspective adopted by organisations such as the ILO where regulation of workplace exploitation is seen as a contributor to fair globalization (Beddgood and Frey, 2015).

Gender stands out as an issue in tourism employment which is emerging as a human rights consideration in its own right. Gender is the subject of increasing scrutiny by tourism employment scholars concerned with effecting change in workplace culture and enhancing individual opportunity (Mooney et al, 2017; Mooney, 2018). Tourism employment has a significant gender imbalance that sees women predominate in low status, low skills roles and face under-representation in high profile technical, managerial and leadership positions (Baum, 2013). Therefore, the consequences of the issues articulated above about tourism work impact disproportionately on women as individuals and on their families and communities and recent interpretations, building on Bunch (1990), accept that the rights of women constitute fundamental human rights (see, for example, Wetzel, 2016).

Tourism employment, then, can challenge human rights at all three levels that we identify above although by no means on a universal basis. Within the workplace, the indicators that point to potential violation of the human rights of individual tourism workers are the most clearly evident through widespread examples of

- Dirty, exploitative and degrading work in poor working conditions for many employees

- Low pay which does not meet basic human needs and may be below the requisite legal minimum wage

- Employment of workers without appropriate documentation as 'illegals' whose civil and social status makes them vulnerable to exploitation and mistreatment, sometimes in conditions that equate to modern slavery 
- Child labour within both the formal and informal tourism economies, including within family businesses

- Blurred dividing lines between employment in tourism (entertainment, night economy, wellness) and sex work with forced participation in the latter

- Discriminatory treatment of women, minorities, the disabled, frequently through structured occupational segmentation and the presence of glass ceilings that prevent opportunity

- Neglect of health and safety requirements for workers across the industry

- Precarious working conditions, illustrated by seasonal unemployment, split shifts, reduced hours, use of agency arrangements and quasi-self-employment status

- Expectation of excessive hours during high season for employees

- Limited or the absence of opportunities for personal growth and development

- Enforced adoption of dress and behavioural codes that may be contrary to religious beliefs and cultural traditions

- Exposure to power inequities in the workplace through interface with customers and fellow workers that may result in harassment and sexual exploitation

Within the family, the individual rights of members may be impacted by tourism employment in the form of

- Child labour within family businesses

- The extended absence of parents and other family members because of unsocial hours of work within tourism or physical relocation that results in long periods away from home (as internal or external migrants, on cruise ships), thus denying children the presence of one or more parents during their formative years

- Responsibility placed on older children within the family to act as surrogate parents to younger siblings and as carers to grandparents, to the detriment of their schooling, their education and their freedom to play and enjoy leisure

Within the community, rights may be impacted by the employment of community members in tourism through

- Enforced compromise to cultural authenticity and values through work roles and responsibilities

- Enforced absence from the community during traditional rites and rituals 
Tourism employment, therefore, can be seen to present real challenges to the human rights of those who work in businesses throughout the industry, in both the formal and informal sectors and in all countries. The challenges are both systemic and structural in nature. The tourism system, operating within the dual realities of a formal (and therefore more regulated) economy and an informal, amorphous and largely unregulated world will, inevitably, be vulnerable to widespread instances of human rights violation in its employment practices. Stochastic demand for tourism services likewise imposes structural pressures on the industry which undoubtedly contribute to human rights violations because the industry is challenged to offer sustained, secure and long-term employment in such circumstances. Intense competition is frequently presented as an explanation if not a justification for some of the excesses within tourism employment - low pay, for example - and there is little doubt that, in many destinations, pressure from tourism intermediaries (such as distribution agents) and, increasingly, direct customer demand has the effect of pushing down prices with invariable consequences for those working in the industry. Tourism as a sector also faces the challenge of interface and, at times, significant overlay with economic sectors that violate both the legal and ethical codes of most countries and confront the industry with the worst excesses of human trafficking for sex work and other employment, narcotic drug distribution and consumption and illegal gambling to give but a few examples. The combined characteristics of work in tourism also presents indirect human rights challenges to those not directly working in the industry, as family and members of the wider community.

Good employers in tourism may acknowledge some of the human rights issues identified above although rarely in such stark terms. Rather they may recognise the need to provide good working conditions in so far as business realities permit and acknowledge the importance of a flexible approach to reciprocal work-life or life-work balance in order to ameliorate some of the more challenging impacts of tourism work on family and community 'others'. It is arguable that a more holistic approach to the interpretation of employment obligations by businesses in tourism, large and small, is required. One such model is that provided by sustainable human resource management or employment practices. We shall now assess the utility of a sustainability approach to employment in tourism as a means of addressing issues of human rights at all three levels.

\section{Applying sustainability principles to tourism employment - is this the answer?}

Framing employment in tourism against the principles that underpin the ILO's notion of decent work and the intent of the UN's sustainable development goals for 2030 allows us to address the conundra of human rights violation at the three levels identified above. This is the insight provided 
by the adoption of an approach that is built on principles of sustainable human resource management (HRM) or sustainable employment (a term we prefer here because of its closer resonance with a human rights agenda). Zaugg et al. (2001:1) provide a definition of sustainable HRM as "long term socially and economically efficient recruitment, development, retainment and disemployment of employees" and represents this, graphically in their model as shown in Figure 2.

\section{$<$ Figure 2 here >}

Similarly, Ehnert et al (2016:90) define sustainable HRM as "the adoption of HRM strategies and practices that enable the achievement of financial, social and ecological goals, with an impact inside and outside of the organisation and over a long-term time horizon while controlling for unintended side effects and negative feedback." Consideration of employment in sustainability terms has emerged as part of a movement to redress what Parkin Hughes et al (2017) call the sustainability skew by which the primary focus of debate in this area was dominated by consideration of environmental rather than social sustainability. This application of sustainability principles to employment is an emergent field that has only recently seen adoption within tourism (Baum et al, 2016; Baum, 2018) with the somewhat depressing conclusion that "in general, hospitality and tourism HRM operates contrary to the principles of sustainable HRM" (Baum et al, 2016:15) .

Ehnert (2009) identifies the key elements within sustainable employment practice as attracting and retaining talent and being recognised as an "employer of choice" highlighting the key components of sustainable HRM practice as

- attracting and retaining talent and being recognised as an 'employer of choice';

- maintaining employee health and safety;

- investing into the skills of the workforce on a long-term basis by developing critical competencies and lifelong learning;

- supporting employees' work-life balance and work-family balance;

- managing aging workforces; creating employee trust, employee trustworthiness and sustained employment relationships;

- exhibiting and fostering (corporate) social responsibility towards employees and their communities ; and

- maintaining a high quality of life for employees and communities. 
Sustainable HRM, therefore, is intended to be proactive in that that it recognises the value of "developing mutually beneficial and regenerative relationships between internal and external resource providers (e.g. employees, their families, education systems, natural environment)" (Ehnert et al., 2016:90).

Ehnert and Harry (2012:223) identify two considerations in support of a sustainability approach to employment and the management of the workplace. They are, firstly, the relationship between an organization and its economic and social environment; and secondly, how a company's internal employment systems and processes accommodate the individual with respect to a range of themes, including "the observation of scarce human resources, of aging workforces and of increasing workrelated health problems". At one level, a sustainable approach to employment represents common sense good practice in relating to the workforce of any organisation and that is certainly true within tourism. Sustainability, however, imposes more fundamental obligations on employers who, above all, are required to think and act on the basis of a long-term vision about work and employment relationships.

On this basis, therefore, Baum et al (2016:15) argue that "the tourism sector must commit to the overarching aim of sustainable employment for all tourism workers, which enshrines the protection of basic human rights, especially for women, children, minorities and those who are less privileged in society". This is substantially the case because, in many regards, the principles that underpin a sustainable approach to employment directly address and provide potential remedy to the human rights issues that we have identified with respect to the tourism sector. Sustainable employment practices provide a framework whereby the neglect of individual worker rights in tourism can be addressed (Baum, 2018). At both a policy and practice level, the tourism industry faces challenges with regard to attracting the best possible workforce, retaining them within the sector, remunerating employees in a way that competes with other industries, providing the workplace environment for "decent work" and offering progressive developmental and career opportunities. In the wider context of a 'pro-work-life balance' approach to tourism employment, recognition of the impact of the consequences that work in tourism can have on the human rights of dependent family members as well as the wider community is equally important. These are issues that may be alleviated by stakeholders in the private and public sectors through the adoption of a sustainable employment "mind set" and applying the key tenets that emanate from this mind set to employment rather than viewing people who work in the industry and their dependents as resources available for exploitation Achieving this objective will require employers to recognise the 
value and contribution of all those who work within tourism businesses on their individual merit; to celebrate diversity in the tourism workplace; to ensure a working environment that is safe and respectful; to provide opportunities that are conducive to learning, development and career progression; to remunerate workers in a way that allows them to live full and healthy lives; and to engage supportively with the non-working lives of all their colleagues. These manifestations of sustainable employment and their consequences for the recognition of the human rights of all those with a stake in the business are easily iterated but making them happen may be more challenging.

\section{Conclusions}

It would be naïve to suggest that a sustainable approach to employment practices in tourism, in itself, would eliminate the violation of associated human rights within the industry. Legal redress, where it exists, appears to be weak in enforcement, poorly resourced by governments and designed to address specific issues rather than acknowledge wider systemic and structural concerns, for example through prosecutions relating to non-payment of the minimum wage or the employment of child or undocumented labour. However, conscious application of sustainable principles and practices in employment within tourism businesses will, inevitably, place a spotlight on an industry culture that permits such violations to persist in the workplaces of many countries. It will not eliminate the cynical and deliberate, generally illegal, violation of human rights within tourism employment - that is more a matter for, on the one hand, under-resourced enforcement authorities and, on the other, informed consumer choice using social media and similar evaluator tools.

Part of the challenge in seeking to remedy human rights abuse within tourism work is the lack of systematic evidence with respect to the dimensions articulated in this paper that are framed in direct human rights language. Researchers need to call out the evidence with respect to human rights and employment in tourism in a manner that is increasingly common in advocacy relating to areas such environmental or land rights. In parallel, there is a requirement for researchers and advocates to avoid hiding behind a more conciliatory and temperate language that merely recognises human rights violations as challenges that are presented as aberrational rather than the norm but without framing the consequences of such violations for what they actually are in human rights terms. There is a need to address work and employment in a way that secures commitment to socially responsible outcomes by large and small companies, representatives of informal economy actors but also by governments in planning and developing their tourism industries (Baum, 2018). There is the requirement for a major educative process of stakeholders that would support change in this regard. Building on this is also the imperative to undertake systematic research and wider 
data gathering about tourism employment that goes beyond government hype about rapid industry growth and consequent economic and job-creation benefits. There is a need to challenge the quality of work and employment that emanates from such planned expansion, testing it against agreed 'decent work' criteria (Baum, 2018). This requires the use of a forensic human rights lens that is currently missing from such analysis.

We acknowledge the aspirational nature of what is being proposed here - we are by no means the first to articulate the need for a seed change with respect to employment practices and the treatment of workers in tourism, with limited impact. Indeed, the basis of the language that has been adopted in the framing of human rights and work by the UN and the ILO is in itself, aspirational, stating individual rights of those in work and enjoining governments and other significant parties (employers, trades unions etc.) to put them into practice through legislative action, practical measures and cultural change. We argue that such change will only take place on the basis of tripartite responsibility and action that is located clearly within a human rights frame by governments through proactive labour market and skills planning, legislation, enforcement and education; by employers through recognition that their social responsibility for sustainable employment requires action of the same order that, increasingly, the industry accepts as a custodian of the natural environment; and by consumers in recognising the social implications of their 'buy cheap' choices for those who work in tourism.

There is no doubt that tourism needs to address its employment challenges from a sustainability and business perspective - in many countries, high labour turnover, the inability to attract top talent to the sector and critical skills shortages, among other considerations, are clearly unsustainable and need to be framed in the wider context of technological, consumer, demographic and general economic change. There is also a need to adopt an approach to tourism employment that is critical of its intersectional relationships in terms of gender, minority, disability and child rights because these are the groups that are at the forefront of vulnerabilities and consequent human rights violations within the workplace, the family and the community. It is argued here that addressing issues over which individual employers do have direct control - levels of remuneration, ensuring payment levels meet legal and ethical standards, managing a safe workplace, recognising the lifework balance needs of all employees - by adopting principles of sustainability in this space will, in turn, help to alleviate the effects of wider, systemic and industry-wide challenges and, through this, reduce violations of human rights at the three inter-connected levels we highlight in this paper. 


\section{References}

Adler, P. A., and Adler, P. (2004). Paradise laborers. Hotel work in the global economy, Ithaca, NY: Cornell University Press

Akgunduz, Y. and Eryilmaz, G. (2018) Does turnover intention mediate the effects of job insecurity and co-worker support on social loafing? International journal of Hospitality Management, 68, 41-49

Alston, P. (ed.) (2005) Labour Rights as Human Rights. Oxford, OUP.

Anderson, B. (2010) Migration, immigration controls and the fashioning of precarious workers, Work, Employment and Society, 24(2), 300-317

Armstrong, R. (2017) Modern slavery: risks for the UK hospitality industry, Progress in Responsible Tourism, 5(1), 67-78

Baum, T. (2013) International Perspectives on Women and Work in Hotels, Catering and Tourism, Geneva: ILO

Baum, T. (2015). Human resources in tourism: Still waiting for change? - A 2015 reprise. Tourism Management, 50, 204-2012.

Baum, T. (2018): Sustainable human resource management as a driver in tourism policy and planning: a serious sin of omission? Journal of Sustainable Tourism, DOI:

10.1080/09669582.2017.1423318

Baum, T. (2019) Hospitality employment 2033: A backcasting perspective (invited paper for 'luminaries' special issue of International Journal of Hospitality Management), International Journal of Hospitality Management, 76(B): 45-52

Baum, T. and Weinz, W. (2010) Developments and challenges in the hospitality and tourism sector: issues paper for discussion at the Global Dialogue Forum for the Hotels, Catering, Tourism Sector, Geneva, ILO

Baum, T., Cheung, C., Kong, H., Kralj, A., Mooney, S., Nguyen Thi Thanh, H., Ramachandran, S., Dropulic Ruzic, M. and Siow, M.L. (2016) Sustainability and the Tourism and Hospitality Workforce: A Thematic Analysis, Sustainability, 8, doi:10.3390/su8080809

Becker, W. S., Carbo, J. A., and Langella, I. M. (2010). Beyond self-interest: Integrating social responsibility and supply chain management with human resource development, Human Resource Development Review, 9, 144-168

Bedggood, M., and Frey, D. F. (2010). Work rights: A human rights based response to poverty, in (ed) Van Bueren, G., Freedom from poverty as a human right: Law's duty to the poor, Paris, France: United Nations Educational, Scientific and Cultural Organization (OECD), 79-112

Bergene, A. C., Boluk, K., and Buckley, E. (2015). Examining the opportunities and challenges of union organisation within the hospitality industry, in (Eds) Jordhus-Lier, D. and Underthun, A. A hospitable world? Organising work and workers in hotels and tourist resorts, London: Routledge, 195-212 
Boardman, J., Johns, A., Petre, D., and Weinz, W. (2015). Opportunities and challenges in the promotion of decent work in hotel global supply chains. Geneva: ILO.

Brown, E., Thomas, N. and Bosselman, R. (2015) Are they leaving or staying: A qualitative analysis of turnover issues for Generation $\mathrm{Y}$ hospitality employees with a hospitality education, International Journal of Hospitality Management, 46, 130-137

Bunch, C. (1990) Women's Rights as Human Rights: Toward a Re-Vision of Human Rights, Human Rights Quarterly, 12, $486-498$

Burns, P. M. (1997). Hard-skills, soft-skills: Undervaluing hospitality's 'service with a smile'. Progress in Tourism and Hospitality Research, 3, 239-248.

Cheruiyot, T.K and Maru, L.C. (2014) Corporate human rights, social responsibility and employee job outcomes in Kenya, International Journal of Law and Management, 56(2), 152 - 168

De Beer, A., Rogerson, C., and Rogerson, J. (2014). Decent work in the South African tourism industry: Evidence from tourist guides. Urban Forum, 25(1), 89-103

Dredge, D. and Gyimóthy, S. (2015) The collaborative economy and tourism: Critical perspectives, questionable claims and silenced voices, Tourism Recreation Research, 40(3), 286-302

Duncan, T., Scott, D. and Baum, T. (2013). The mobilities of hospitality work: An exploration of issues and debates. Annals of Tourism Research, 41(4), 1-19

Ehnert, I. (2009). Sustainable human resource management. Berlin: Springer.

Ehnert, I., and Harry, W. (2012). Recent developments and future prospects on sustainable human resource management: Introduction to the special issue. Management Revue, 23(3), 221-238.

Ehnert, I., Parsa, S., Roper, I., Wagner, M., and Muller- Camen, M. (2016). Reporting on sustainability and HRM: A comparative study of sustainability reporting practices by the world's largest companies. The International Journal of Human Resource Management, 27(1), 88-108.

Fenwick, C. and Novitz, T. (eds.). 2010. Human Rights at Work. Perspectives on Law and Regulation. Oxford/Portland: Hart

Flodman Becker, K. (2004) The Informal Economy, Stockholm: Department for Infrastructure and Economic Co-operation

Frey, D. and MacNaughton, G. (2016) A Human Rights Lens on Full Employment and Decent Work in the 2030 Sustainable Development Agenda, Journal of Workplace Rights, 6(2), 1-13

Furunes, T. (2005) Training Paradox in the Hotel Industry, Scandinavian Journal of Hospitality and Tourism, 5(3), 231-248

Gross, J. A. (2010). A shameful business: The case for human rights in the American workplace. Ithaca, NY: Cornell University Press

Gursoy, D., Geng-Qing Chi, C., and Karadag, E. (2013). Generational differences in work values and attitudes among frontline and service contact employees. International Journal of Hospitality Management, 32(1), 40-48. 
Hughes, E. and Scheyvens, R. (2016) Corporate social responsibility in tourism post-2015: a Development First approach, Tourism Geographies, 18(5), 469-482

International Labour Organization (ILO). (2012). Decent work indicators. Concepts and definitions. Geneva: ILO

Islam, M. A., and Jain, A. (2013). Workplace human rights reporting: A study of Australian garment and retail companies. Australian Accounting Review, 23(2), 102-116

Iverson, K. (2000) The paradox of the contented female manager: an empirical investigation of gender differences in pay expectation in the hospitality industry, International Journal of Hospitality Management, 19, 33-51

Janta, H., Brown, L., Lugosi, P., and Ladkin, A. (2012). Migrant relationships and tourism employment. Annals of Tourism Research, 38(4), 1322-1343

Jones, T., Ram, M. and Edwards, P. (2004) Illegal immigrants and the informal economy: workers and employer experiences in the Asian underground economy, International Journal of Economic Development, 6(2), 98-119

Knox, A. (2016) Coffee nation: an analysis of jobs in Australia's café industry, Asia Pacific Journal of Human Resources, 54, 369-387

Knox, A., Warhurst, C., Nickson, D., and Dutton, E. (2015). More than a feeling: Using hotel room attendants to improve understanding of job quality. The International Journal of Human Resource Management, 26(12), 1547-1567

Kolben, K. (2010) Labor Rights as Human Rights?, Virginia Journal of International Law, 50( 2), 450484

Ladkin, A. (2011). Exploring tourism labor. Annals of Tourism Research, 38(3), 1135-1155

Leonard M. (2000), Coping strategies in developed and developing societies: the workings of the informal economy, Journal of International Development 12 (8), 1069-85

McDonald R (1994), Fiddly jobs, undeclared working and the something for nothing society, Work, Employment and Society 8, 507-530

McDowell, L., Batnitzky, A. and Dyer, S. (2007). Division, segmentation, and interpellation: The embodied labors of migrant workers in a greater London hotel. Economic Geography, 83(1), 1-25.

McDowell L, Batnitzky A. and Dyer S (2009) Precarious work and economic migration: Emerging immigrant divisions of labour in Greater London's service sector. International Journal of Urban and Regional Research 33(1): 3-25

Mantouvalou, V. (2012) Are labour rights human rights? European Labour Law Journal, 3(2), 151-172

McCabe, S. and Diekmann A. (2015) The rights to tourism: reflections on social tourism and human rights, Tourism Recreation Research, 40(2): 194-204 
Meyer, W. (2015) Testing theories of labor rights and development, Human Rights Quarterly, 37(2), 414-437

Mooney, S. (2018). Jobs for the girls? Women's employment and career progression in the hospitality industry. In R. Burke and Christensen Hughes (Eds.), Handbook of hospitality human resource management (pp. 184-215). London and New York: Edward Elgar Publishing

Mooney, S., Ryan, I., and Harris, C. (2017). The intersections of gender with age and ethnicity in hotel careers: still the same old privileges? Gender, Work and Organization, 24(4), 360-375

Moragra, C. (2017) Nature and Determinants of Informal Employment among Grab and Uber Drivers in Metro Manila, unpublished Master of Industrial Relations thesis, Manila: University of the Philippines Diliman

Morgeson, F. P., Aguinis, H., Waldman, D. A., and Siegel, D. S. (2013). Extending corporate social responsibility research to the human resource management and organizational behavior domains: $A$ look to the future, Personnel Psychology, 66, 805-824.

Nickson, D., Warhurst, C., and Witz, A. (2003). The labour of aesthetics and the aesthetics of organization. Organization, 10(1), 33-54.

Nguyen, T.T.H and Ngo, T.M.H. (2019) (eds) Children's Rights in the Tourism Industry. The Cases of Vietnam and Mynamar, Hanoi: Hong Duc Publishing House

O'Brien, C.M. and Dhanarajan, S., (2016) The corporate responsibility to respect human rights: a status review , Accounting, Auditing and Accountability Journal, 29(4): 542 - 567

Parkin Hughes, C., Semeijn, J. and Caniels, M. (2017) The sustainability skew, Current Opinion in Environmental Sustainability, 28, 58-63

Pienaar, J., and Willemse, S. A. (2008). Burnout, engagement, coping and general health of service employees in the hospitality industry. Tourism Management, 29(6), 1053-1063.

Pizam, A. (2015) Is the foodservice industry only composed of low-paid and unskilled jobs? International Journal of Hospitality Management, 50, 153-154

Poulston, J. (2008). Rationales for employee theft in hospitality: Excuses, excuses. Journal of Hospitality and Tourism Management, 15, 49-58

Puneet, A. (2015) Human rights and social aspects of tourism, Zenith International Journal of Multidisciplinary Research, 5(2): 19-22

Robinson, R. (2013). Darker still: Present-day slavery in hospitality and tourism services. Hospitality and Society, 3(2), 93-110.

Robinson, R., Martins, A., Solnet, D. and Baum, T. (2019) Sustaining precarity: critically examining tourism and employment, Journal of Sustainable Tourism, DOI: 10.1080/09669582.2018.1538230

Ross A (2009) Nice Work if You Can Get it: Life and Labor in Precarious Times. New York: New York University Press

Sandoff, M. (2005) Customization and standardization in hotels - a paradox or not?, International 
Journal of Contemporary Hospitality Management, 17(6), 529 - 535

Shaw, G. and Williams, A. (1994). Critical issues in tourism: A geographical perspective. Oxford: Blackwell.

Sonmez, S., Apostolopoulos, Y., Lemke, M. and Hsieh, Y.C. (2016) Simulation Modelling of Occupational Health of Tourism and Hospitality Workers, Tourism Travel and Research Association: Advancing Tourism Research Globally. 21., Retrieved at http://scholarworks.umass.edu/ttra/2016/Academic_Papers_Oral/21

Solnet, D., Kralj, A. and Baum, $T_{-}$(2014) 360 degrees of pressure: the changing role of the HR professional in the international hospitality industry Journal of Hospitality and Tourism Research 39(2), 271-292

Solnet, D., Nickson, D., Robinson, R. N. S., Kralj, A. and Baum, T. (2014) Discourse implementation in Australia and Scotland: hot air or making a difference? Tourism Analysis. 19(5), 609-623

Solnet, D., Baum, T., Kralj, A., Robinson, R., Ritchie, B. and Olsen, M. (2014) The Asia-Pacific tourism workforce of the future: using Delphi techniques to identify possible scenarios Journal of Travel Research, 53(6):693-704

Solnet, D., Baum, T., Robinson, R. and Lockstone-Binney, L, (2016), What about the workers? Roles and skills for employees in hotels of the future, Journal of Vacation Marketing, 22, 212-226

The Guardian. (2016). Michel Roux Jr admits restaurant staff get no share of service charge. The Guardian, December 16. Retrieved from https://www.theguardian.com/lifeandstyle/2016/dec/15/michel-roux-ir-restaurant-staff-no-shareservice-charge-le-gavroche? $\mathrm{CMP}=$ share btn link

United Nations (1948) Universal Declaration on Human Rights, Retrieved at http://www.un.org/en/universal-declaration-human-rights/

United Nations (2011) Guiding Principles (GPs) on Business and Human Rights, New York: UN

United Nations. (2015). Transforming our world: The 2030 agenda for sustainable development. Retrieved from

https://sustainabledevelopment.un.org/content/documents/21252030\%20Agenda\%20for\%20Sustai nable\%20Development\%20web.pdf

Voegtlin, C. and Greenwood, M. (2016) Corporate social responsibility and human resource management: A systematic review and conceptual analysis, Human Resource Management Review, 26, 181-197

Westwood, A. (2002). Is new work good work? London: The Work Foundation

Wetzel, J.W. (2016) The World of Women: In Pursuit of Human Rights, Basingstoke: MacMillan

Winchenbach, A., Hanna, P. and Miller, G. (2019): Rethinking decent work: the value of dignity in tourism employment, Journal of Sustainable Tourism, DOI: 10.1080/09669582.2019.1566346

Wood, R. (1997). Working in hotels and catering (2nd ed.). London: International Thomson 
Zaugg, R.J., Blum, A. and Thom, N. (2001) Sustainability in human resource management, Evaluation Report, Bern: University of Berne/ European Association of Personnel Management 
Figure 1: Three dimensions of human rights in tourism employment

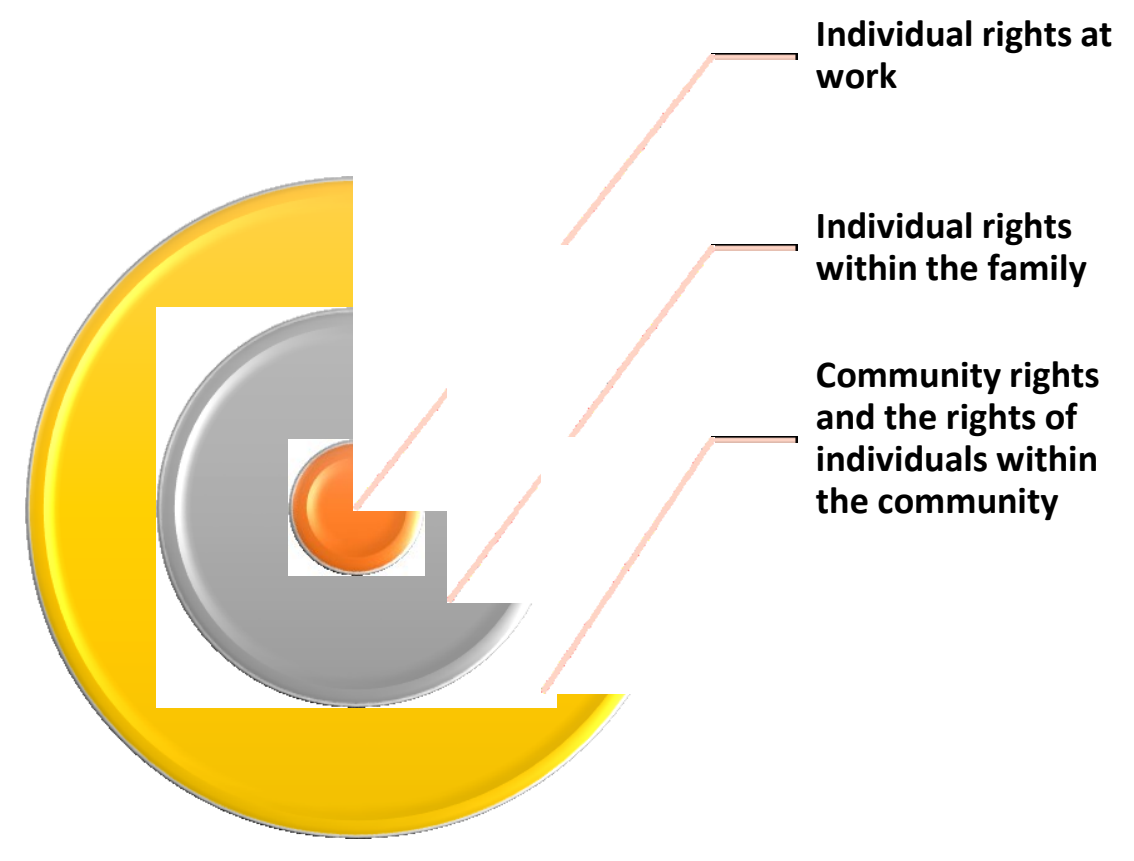

Figure 2: Model of Sustainable HRM (Zaugg et al, 2001:3)

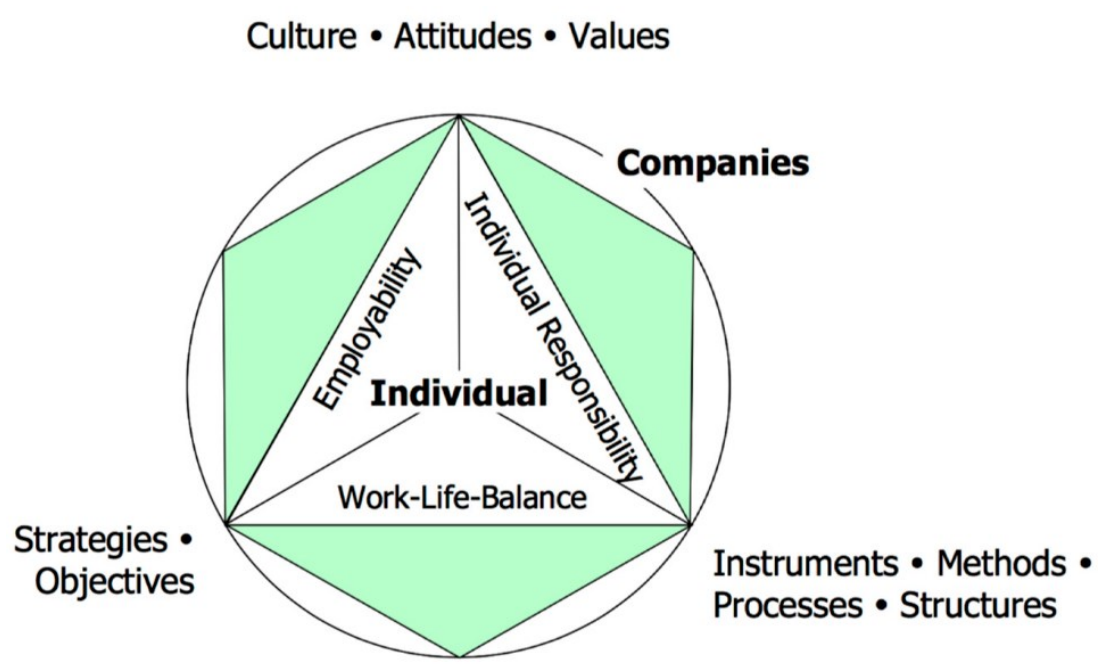

